\title{
Components of the Endogenous Cannabinoid System as Potential Biomarkers for Interstitial Cystitis/Bladder Pain Syndrome
}

\author{
Saki Sultana ${ }^{1, *(\mathbb{D}}$, Geraint Berger ${ }^{1,2}$ and Christian Lehmann ${ }^{1,2}$ (D) \\ 1 Department of Pharmacology, Dalhousie University, Halifax, NS B3H 4R2, Canada; gr869131@dal.ca (G.B.); \\ chlehmann@dal.ca (C.L.) \\ 2 Department of Anesthesia, Pain Management and Perioperative Medicine, Dalhousie University, \\ Halifax, NS B3H 4R2, Canada \\ * Correspondence: saki.sultana@dal.ca
}

check for

updates

Citation: Sultana, S.; Berger, G.;

Lehmann, C. Components of the Endogenous Cannabinoid System as Potential Biomarkers for Interstitial Cystitis/Bladder Pain Syndrome. Diagnostics 2022, 12, 19. https:// doi.org/10.3390/diagnostics12010019 Academic Editors: Jochen Neuhaus, Andreas Gonsior and Mandy Berndt-Paetz

Received: 15 November 2021 Accepted: 20 December 2021 Published: 23 December 2021

Publisher's Note: MDPI stays neutral with regard to jurisdictional claims in published maps and institutional affiliations.

Copyright: (c) 2021 by the authors. Licensee MDPI, Basel, Switzerland. This article is an open access article distributed under the terms and conditions of the Creative Commons Attribution (CC BY) license (https:// creativecommons.org/licenses/by/ $4.0 /)$.

\begin{abstract}
Interstitial cystitis/bladder pain syndrome (IC/BPS) is a chronic condition causing bladder pressure and pain. The condition is of unknown etiology and is often accompanied by other symptoms, including chronic pelvic pain, increased urinary urgency, and frequency. There is no definitive diagnosis for IC/BPS, and treatment options are currently limited to physical therapy and medications to help alleviate symptoms. The endogenous cannabinoid system (ECS) is an important regulator of numerous physiological systems, including the urinary system. Modulations of the ECS have been shown to be beneficial for IC/BPS-associated pain and inflammation in rodents. As an attempt to identify potential biomarkers for IC/BPS, we reviewed experimental studies where the components of the ECS have been quantified in experimental models of IC/BPS. Further investigations using well-defined animal models and patients' data are required to obtain stronger evidence regarding the potential for ECS components to be definitive biomarkers for IC/BPS.
\end{abstract}

Keywords: endocannabinoid system; interstitial cystitis; bladder pain syndrome; biomarker; cannabinoid receptor; endocannabinoid ligand; endocannabinoid enzyme

\section{Introduction}

Interstitial cystitis/bladder pain syndrome (IC/BPS) is a chronic condition causing pelvic pain, pressure, or discomfort that is perceived to be related to the urinary bladder, often accompanied by various other urinary symptoms, such as increased urinary urgency and frequency [1,2]. These symptoms present in the absence of infection or other identifiable causes, reflecting the idiopathic nature of the disorder [3,4]. Symptoms often overlap with other genitourinary disorders, including chronic urethral syndrome, overactive bladder, vulvodynia, and endometriosis, leading to complications in the evaluation and subsequent treatment [5,6]. IC can be ulcerative or non-ulcerative although the distinct pathophysiology and clinical presentations of these two sub-types are not properly defined yet $[7,8]$. IC predominantly affects females, with an estimated 5:1 female to male ratio [9], with approximately $2.7-6.5 \%$ of American women experiencing symptoms consistent with an IC diagnosis [10]. However, only $9.7 \%$ report receiving a diagnosis with IC [11]. The diagnosis of IC can be challenging to attain, with patients often presenting with a wide variety of symptoms, physical examination findings, and clinical test responses [12-14]. National Institute of Diabetes and Digestive and Kidney Diseases (NIDDK) has set specific guidelines for the diagnosis of IC/BPS; however, proper diagnosis of the condition essentially depends on the exclusion of other disorders and is subjected to the physician's judgment in many cases $[15,16]$. The variability of symptoms and complexity of diagnosis often leads to misdiagnosis, underdiagnosis, and/or delayed diagnosis of IC/BPS, which may lead to delayed or inappropriate treatment regimens. The diagnosis of similar diseases 
with overlapping symptoms has previously been resolved through the use of biomarkers [17]. This review aims to assess the prospect of the components of the endogenous cannabinoid system (ECS) as diagnostic biomarkers for IC/BPS.

\subsection{Pathophysiology of IC/BPS}

The pathogenesis and etiology of IC/BPS are multifactorial $[18,19]$. Bladder epithelial dysfunction, neurogenic inflammation, mast cell activation, and autoimmunity are associated with the pathogenesis of IC/BPS [20]. Disruption of the bladder urothelial permeability (also known as leaky urothelium) is the most common feature in IC/BPS, but the mechanism of urothelial disruption is still unclear [18,21]. Urothelial disruption in inflammation and irritation can be caused by any bacterial or fungal infection, trauma/stress, foreign bodies, or chemicals $[7,20]$. The disrupted urothelial barrier facilitates the migration of urinary solutes from urine into the bladder wall and triggers the symptoms associated with IC/BPS. Leakage of urinary potassium into the suburothelium results in depolarization of nerves and muscles and consequently triggers tissue injury [19,22].

Activation and infiltration of mast cells in the urothelium is another common pathological feature in IC/BPS. Infiltration of eosinophils and T lymphocytes is observed as well, suggesting the possible immune dysregulation associated with IC/BPS. Activated mast cells secrete cytokines and several proinflammatory and nociceptive mediators, including substance $\mathrm{P}$ and nerve growth factor (NGF), which are associated with the proliferation of nerve fibers $[16,23]$.

Abnormal expression of cell adhesion proteins (uroplakins, chondroitin sulfate), tight junction protein zonula occludens-1 (ZO-1), E-cadherin, and bacterial defense molecule (GP51) in the bladder tissues of patients with IC /BPS strongly suggest abnormal differentiation in the bladder with IC/BPS [18,23]. Aberrant differentiation in the bladder urothelium observed in IC/BPS results in the altered synthesis of several proteoglycans [24,25]. Increased apoptosis and elevated E-cadherin expression in the bladder of IC/BPS patients is indicative of chronic inflammation associated with IC/BPS [25,26]. Upregulation of inflammatory mediators, especially TNF- $\alpha$ and p38 mitogen-activated protein kinase, are also linked to the increased apoptosis in the IC/BPS $[7,26]$.

The bladder epithelial cells are acutely declined in patients with IC/BPS. This decrease in cellular proliferation may be caused by an antiproliferative factor (APF) produced by the bladder epithelial cells [27]. APF causes reversible inhibition of heparin-binding epidermal growth factor-like (HB-EGF-like) growth factor production and normal epithelial cell proliferation $[26,27]$.

\subsection{Biomarkers for IC/BPS}

The lack of consensus on the pathophysiology of IC/BPS and the presence of overlapping syndrome among IC/BPS and other urinary disorders emphasize the urgency of the identification of a biomarker for proper diagnosis, prognosis, and treatment of this painful bladder condition. Investigation of potential biomarkers for IC/BPS has mostly been done focusing on the urothelial differentiation proteins, proteoglycan proteins, urinary nerve growth factors, cytokines, and chemokines [7]. Until now, a unique APF produced by the bladder epithelial cells and secreted in the urine of IC patients is the most promising urinary biomarker for IC/BPS [7,28-31]. APF is associated with the suppression of cell growth and differentiation and increases in transcellular permeability. In-vitro studies have demonstrated that cell proliferation and membrane integrity was restored upon removal of APF from the cell culture media [32]. APF also played a role in the therapeutic effect of hydrodistension in patients with IC/BPS [33].

Available evidence also suggests HB-EGF and EGF as potential markers for IC/ BPS [7,33-35]. NGF also holds promise as a biomarker for IC/BPS as NGF is significantly upregulated in the bladder epithelial cells and urine of IC/BPS patients [7,36-38]. Among the cytokines and chemokines, urine IL-6, IL-8, and serum IL-6, IL-8, IL-1 $\beta$, and TNF- $\alpha$ have shown promise [7]. However, a single cytokine in the urine or serum may not 
be a sole confirmation for the IC/BPS, as aberrant cytokine levels might be associated with other inflammatory conditions. A combination of several specific cytokines in the urine will be more appropriate for the confirmation of IC/BPS and differentiate it from other urinary conditions [7]. Determination of a genetic biomarker for the IC/BPS is in progress as well, which will shed light on the predisposing factors for IC/BPS $[23,39,40]$.

\subsection{The Endogenous Cannabinoid System}

The endogenous cannabinoid system (ECS) is a biological lipid-based signalling system involved in a wide range of physiological functions, including but not limited to metabolism, neurotransmission, cognition, pain-sensation, and inflammation [41,42]. The discovery of endogenous bioactive lipids (endocannabinoids, ECs) that function through the same receptors that mediate the actions of tetrahydrocannabinol prompted the discovery of the ECS. Broadly, the ECS is comprised of three major components: the endocannabinoid signalling molecules/ligands, the enzymes involved in EC biosynthesis and degradation, and receptors upon which cannabinoid ligands function (Figure 1). Of the endocannabinoids, the most well studied are anandamide (AEA), and 2-arachidonylglycerol (2-AG), which are synthesized on-demand through enzymatic conversion of membrane lipids [43]. 2-AG is synthesized by the conversion of 1,2-diacylglycerol (DAG) to 2-AG by DAGlipase [44] and AEA by conversion of N-arachidonylphosphatidylethanolamine (NAPE) by the enzyme phospholipase D [44]. Cannabinoid ligands function through membrane cannabinoid receptors 1 and 2 (CB1R and CB2R), which are G-protein coupled receptors expressed widely throughout the human body. The CB1R is predominantly expressed in the central nervous system, while the CB2R is localized to cells of the immune system and peripheral tissues $[44,45]$. CB1R accounts for the psychoactive property of cannabinoids, and CB2R is the key regulator of inflammation and immune regulation of cannabinoids. The ECS is a transiently active system, relying upon enzymatic degradation of ECs to terminate signalling [45].

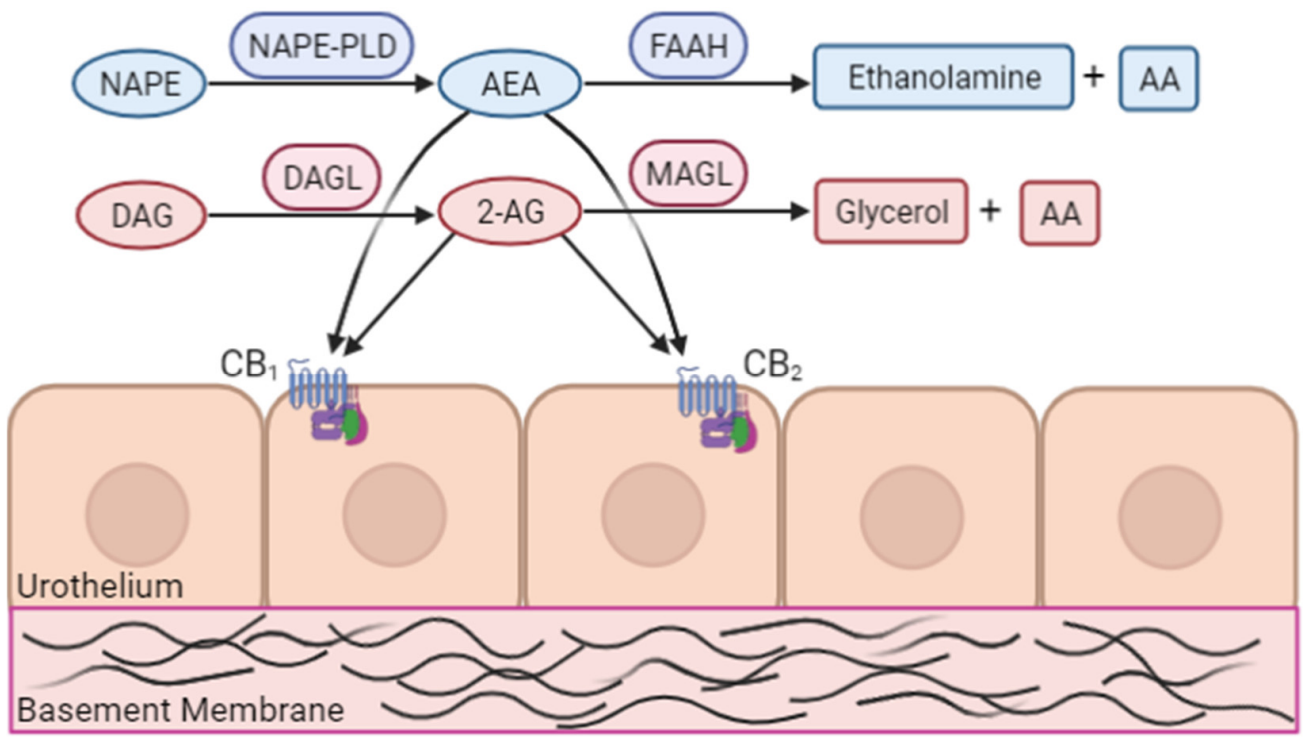

Figure 1. The endocannabinoid system (shown on urothelium) highlights key endocannabinoids, cannabinoid receptors, and synthesis/degradative enzymes. NAPE, N-acylphosphatidylethanolamine; NAPE-PLD, N-acyl-phosphatidylethanolamine-specific phospholipase D; 2-AG, 2-arachidonoylglycerol; AA, arachidonic acid; DAG, diacylglycerol; DAGL, diacyl-glycerol lipase; CB1, cannabinoid receptor 1; CB2, cannabinoid receptor 2; FAAH, fatty acid amide hydrolase; MAGL, monoacylglycerol lipase. (Image created with BioRender). 


\subsection{The Endocannabinoid System and the Urinary System}

In recent years, various studies have shown a strong link between the ECS and bladder physiology. The ECS can downregulate sensory bladder function during urine storage and micturition under normal physiological conditions $[46,47]$. Fatty acid amide hydrolase (FAAH), the EC-metabolic enzyme that degrades AEA, is expressed in the urothelium of the bladder in mice, rats, and humans $[47,48]$. CB1R and CB2R are present in the bladders of various species, including rodents [49,50], monkeys [51], and humans [52,53]. The expression of both receptors in the human detrusor and urothelium has been confirmed using real-time quantitative polymerase chain reaction (qPCR), immunohistochemistry, and western blot analysis [53]. Differential expression within the tissues of the bladder has been shown, with both receptors showing greater expression in the urothelium compared to the detrusor [52]. Urothelial cells express an abundance of CB2R [49-51]. Moreover, both receptors have been identified on afferent and cholinergic nerves within the bladder wall [54], where they co-localize with receptors involved in sensory and nociceptive signalling, including transient receptor potential vanilloid [55], transient receptor potential ankyrin 1 [56], and calcitonin gene-related protein [51].

Modulations of the ECS have been proven to be beneficial in urinary diseases, including lower urinary tract symptoms in painful bladder syndromes (PBS) and overactive bladder $(\mathrm{OAB})[46,47,57]$. Activation of the CB2R resulted in suppression of the sensitizing effects of the nerve growth factor on afferent nerve signaling and blocked increased peripheral mechanical sensitivity associated with inflammatory cystitis in mice $[50,58]$. Pharmacological inhibition of FAAH attenuated hyper-reflexia in inflamed rat bladders [59]. FAAH inhibition also improved bladder storage capacity, reduced frequency and residual volume, and increased threshold pressure in overactive bladders in rats [47]. The endocannabinoid ligand AEA inhibited nerve-mediated contractions in rodent bladders in a CB1R-dependent manner $[47,60]$. The effect of AEA on bladder contractions was lower in rats compared to mice, indicative of interspecies variation in AEA-dependent contractions in bladder tissue $[47,60]$. Systemic treatment of rats with cyclophosphamide-induced bladder inflammation with AEA or PEA attenuated viscero-visceral hyperreflexia [61]. AEA and PEA also prevented hyperalgesia associated with urinary bladder inflammation in rats [59,62]. Taken together, it is evident that the ECS has a strong regulatory effect on the urinary system.

We have reviewed the studies investigating the ECS in experimental animal models of IC/BPS and documented the changes in the levels of individual components of the ECS to determine whether any component of the ECS can serve as a potential biomarker to aid in the diagnosis of IC/BPS.

\section{Search Strategy for the Review}

PubMed, ScienceDirect, and Google Scholar databases were searched using the following keywords in various combinations: endocannabinoid system, endocannabinoids, interstitial cystitis, bladder pain syndrome, cannabinoid receptors, fatty acid amide hydrolase, monoacylglycerol lipase, anandamide, 2-arachidonoylglycerol, and biomarker. All studies up to 30 August 2021 were examined for the selection process. A manual search of references was performed on the bibliography of each selected article to further identify studies not captured by the above-mentioned keywords. Only articles published in English were considered.

\section{Results}

\subsection{Cannabinoid Receptor Expression in IC/BPS}

We identified seven studies where the expression of CB1R and/or CB2R was detected either at mRNA (RT-PCR/q-PCR) or protein level (western blot analysis or immunofluorescence staining) in experimental animal models of IC/BPS (Table 1). The CB1R expression (mRNA or protein) remained unchanged in all the relevant studies except the study by Pessina et al., where CB1R mRNA was upregulated in a cyclophosphamide (CYP)-induced cystitis model using female Wistar rats [63]. The upregulation of CB1R in this study could 
be model-dependent. On the other hand, the CB2R level was either upregulated or remained unchanged in experimental models of IC/BPS. Merriam et al. reported a significant increase of CB2R protein in the detrusor in acute cystitis models and a significant increase of CB2R protein both in the detrusor and mucosa in chronic cystitis in rats having two different backgrounds (Sprague-Dawley and Wistar) [49]. No change in the CB2R expression reported by some studies could be associated with the models used for those studies. As a good number of studies reported significant upregulation of CB2R in animal models of IC/BPS, CB2R appears to be promising as a biomarker for IC/BPS. This is a subject of further investigation whether there is any correlation between the upregulation of CB2R and disease severity in IC/BPS.

Table 1. Endocannabinoid Receptor Expression in the Bladder Tissue of Experimental IC/BPS models.

\begin{tabular}{|c|c|c|c|c|c|}
\hline Animals & Condition & $\begin{array}{l}\text { Method of Induction } \\
\text { of IC }\end{array}$ & CB1R & CB2R & Reference \\
\hline $\begin{array}{l}\text { Female Wistar } \\
\text { rats }\end{array}$ & $\begin{array}{l}\text { CYP-induced } \\
\text { cystitis }\end{array}$ & $\begin{array}{c}\text { CYP }(20 \mathrm{mg} / \mathrm{kg}), \\
\text { intraperitoneal (i.p.) } \\
\text { injection }\end{array}$ & $\begin{array}{l}\text { Upregulation of } \\
\text { CB1R mRNA } \\
\text { expression }\end{array}$ & $\begin{array}{l}\text { No change in CB2R } \\
\text { mRNA expression }\end{array}$ & [63] \\
\hline $\begin{array}{c}\text { Female } \\
\text { C57BL/6NH } \\
\text { mice }\end{array}$ & $\begin{array}{l}\text { Acrolein-induced } \\
\text { cystitis }\end{array}$ & $\begin{array}{c}\text { Acrolein ( } 1 \mathrm{mM}, \\
150-\mu \mathrm{L} \text { total volume), } \\
\text { intravesical instillation }\end{array}$ & Not reported & $\begin{array}{l}\text { No change in CB2R } \\
\text { abundance in urothe- } \\
\text { lium/suburothelium } \\
\text { (western blot analysis) }\end{array}$ & [50] \\
\hline Male CD1 mice & $\begin{array}{l}\text { Lipopolysaccharide } \\
\text { (LPS)-induced } \\
\text { cystitis }\end{array}$ & $\begin{array}{c}\text { LPS } \\
\text { (Doses } 20 \mathrm{mg} / \mathrm{kg} \text { and } \\
25 \mathrm{mg} / \mathrm{kg} \text { ), i.p. } \\
\text { injection }\end{array}$ & $\begin{array}{l}\text { No change in } \\
\text { CB1R mRNA } \\
\text { expression }\end{array}$ & $\begin{array}{c}\text { Increase in CB2R mRNA } \\
\text { expression }\end{array}$ & [64] \\
\hline $\begin{array}{c}\text { Female } \\
\text { C57BL/6J mice }\end{array}$ & $\begin{array}{l}\text { CYP-induced } \\
\text { cystitis }\end{array}$ & $\begin{array}{l}\text { CYP (150 mg/kg), i.p. } \\
\text { injection }\end{array}$ & Not reported & $\begin{array}{l}\text { Significant increase in } \\
\text { CB2R mRNA expression }\end{array}$ & [65] \\
\hline $\begin{array}{c}\text { Female } \\
\text { C57BL/6NH } \\
\text { mice }\end{array}$ & $\begin{array}{l}\text { Acrolein-induced } \\
\text { cystitis }\end{array}$ & $\begin{array}{c}\text { Acrolein ( } 1 \mathrm{mM}, \\
150-\mu \mathrm{L} \text { total volume), } \\
\text { intravesical instillation }\end{array}$ & Not reported & $\begin{array}{c}\text { CB2R-like } \\
\text { immunoreactivity in } \\
\text { urothelium remained } \\
\text { unchanged }\end{array}$ & [58] \\
\hline $\begin{array}{l}\text { Female C57BL } / 6 \\
\text { mice }\end{array}$ & $\begin{array}{l}\text { CYP-induced } \\
\text { cystitis }\end{array}$ & $\begin{array}{l}\text { CYP (300 mg/kg) i.p. } \\
\text { injection }\end{array}$ & $\begin{array}{l}\text { No change in } \\
\text { CB1R expression } \\
\text { pattern (immuno- } \\
\text { fluorescence } \\
\text { staining) }\end{array}$ & Not reported & [55] \\
\hline $\begin{array}{c}\text { Female } \\
\text { Sprague-Dawley } \\
\text { and Wistar rats }\end{array}$ & $\begin{array}{l}\text { Acrolein-induced } \\
\text { acute and chronic } \\
\text { cystitis }\end{array}$ & $\begin{array}{l}\text { Acute cystitis: One } \\
\text { dose of acrolein } \\
\text { Chronic cystitis: } \\
\text { Three doses of acrolein } \\
\text { at } 72-\mathrm{h} \text { intervals. } \\
\text { Acrolein dose: }(400 \mu \mathrm{L} \text {, } \\
1 \mathrm{mM})\end{array}$ & $\begin{array}{l}\text { Acute cystitis: } \\
\text { No significant } \\
\text { change in CB1R } \\
\text { protein; } \\
\text { No change in } \\
\text { CB1R mRNA } \\
\text { expression } \\
\text { Chronic cystitis: } \\
\text { No change in } \\
\text { CB1R protein }\end{array}$ & $\begin{array}{c}\text { Acute cystitis: } \\
\text { Significant increase in } \\
\text { CB2R protein in the } \\
\text { detrusor but not in the } \\
\text { mucosa; } \\
\text { No change in CB2R } \\
\text { mRNA expression } \\
\text { Chronic cystitis: } \\
\text { Significant increase in } \\
\text { CB2R protein in detrusor } \\
\text { and mucosa; } \\
\text { CB2R mRNA increased }\end{array}$ & [49] \\
\hline
\end{tabular}

\subsection{Endocannabinoid Ligands and Fatty Acid Ethanolamides in IC/BPS}

We found five studies reporting the levels of endocannabinoid ligands and fatty acid ethanolamides in experimental models of interstitial cystitis (Table 2). Fatty acid ethanolamides are endocannabinoid-like compounds that interact with receptors outside of CB1R and CB2R [66]. Palmitoylethanolamide (PEA) was significantly increased in the bladder tissue of all the relevant studies except the study by Charrua et al., where PEA was 
downregulated in an LPS-induced cystitis model using Wistar rats [67]. The time-point for measuring the PEA content of the study by Charrua et al. was $24 \mathrm{~h}$, which was different from the other two studies reporting higher levels of PEA in experimental IC/BPS. Merriam et al. reported the bladder PEA content after $48 \mathrm{~h}$ of instillation of acrolein [68], and Pessina et al., measured the PEA level after $3.5 \mathrm{~h}$ of intraperitoneal injection of CYP in rats [63]. Pessina et al., also reported the protective role of PEA in CYP-induced cystitis in rats, where intraperitoneal administration of ultra-micronized PEA attenuated pain behavior, voiding episodes, and bladder inflammation associated with CYP administration in female Wistar rats. This beneficial role of PEA in cystitis models indicates that elevation of PEA level is a defensive response of bladder to counteract local inflammation, but further investigation is required to confirm this [63].

Three studies reported significant increases in the AEA content, and two studies reported no change in the level of AEA in the bladder tissue of rats in experimental IC/BPS (Table 2). The experimental models of the studies in which the AEA level remained unchanged were different from the other studies reporting the level of AEA. Pessina et al. administered low-dose CYP $(20 \mathrm{mg} / \mathrm{kg})$ in rats [63], and Wang et al., used C57BL/6J mice for induction of cystitis [69], which could have possibly contributed to no detectable change in the bladder AEA content. Nonetheless, the underlying mechanisms for the diverging changes in PEA and AEA concentrations are unclear. The rates of synthesis and hydrolysis of the ethanolamides might be different in different models. Degradation of AEA and PEA by mechanisms other than hydrolysis may also play an important role in their balance.

2-AG and oleoylethanolamide (OEA) levels did not show any trend in the studies in which these two components were measured. One study reported a decrease in the level of 2-AG, whereas another study did not find any change in the bladder content of 2-AG. In the case of OEA, one study reported a significant increase in OEA, and another study showed no change in the level of OEA (Table 2).

As PEA and AEA were mostly upregulated in experimental models of IC/BPS, these two components can be considered as candidates for diagnostic biomarkers for IC/BPS.

Table 2. Endocannabinoid Ligands and Fatty Acid Ethanolamides in the Bladder Tissue of Experimental IC/BPS Models.

\begin{tabular}{|c|c|c|c|c|}
\hline Animals & Condition & $\begin{array}{c}\text { Method of Induction of } \\
\text { IC }\end{array}$ & $\begin{array}{l}\text { Endocannabinoid Ligands } \\
\text { and Fatty Acid Amides }\end{array}$ & Reference \\
\hline Female Wistar rats & CYP-induced cystitis & $\begin{array}{l}\text { CYP }(20 \mathrm{mg} / \mathrm{kg}), \text { i.p. } \\
\text { injection }\end{array}$ & $\begin{array}{c}\text { Increased level of PEA; } \\
\text { No change in AEA level; } \\
\text { Significant decrease in 2-AG } \\
\text { level }\end{array}$ & [63] \\
\hline Female Wistar rats & $\begin{array}{l}\text { Acrolein-induced } \\
\text { bladder inflamma- } \\
\text { tion/hyperalgesia }\end{array}$ & $\begin{array}{l}\text { Acrolein }(1 \mathrm{mM}, 400-\mu \mathrm{L} \\
\quad \text { total volume }) \\
\text { intravesical instillation }\end{array}$ & $\begin{array}{c}\text { Significant increase in PEA, } \\
\text { AEA, and OEA }\end{array}$ & [68] \\
\hline Female Wistar rats & CYP-induced cystitis & $\begin{array}{l}\text { Two schedules of i.p. } \\
\text { injections of CYP: single } \\
\text { injection }(200 \mathrm{mg} / \mathrm{kg}) \text { or } \\
\text { three injections }(75 \\
\mathrm{mg} / \mathrm{kg} \text { ) each on days } 1,4 \text {, } \\
\text { and } 7 \text {. }\end{array}$ & $\begin{array}{c}\text { Significant increase in AEA } \\
\text { levels in both cases at each } \\
\text { time points }\end{array}$ & [70] \\
\hline $\begin{array}{l}\text { Male FAAH KO and } \\
\text { WT mice having } \\
\text { C57BL/6J background }\end{array}$ & CYP-induced cystitis & $\begin{array}{l}\text { CYP (150 mg/kg), i.p. } \\
\text { injection }\end{array}$ & $\begin{array}{l}\text { No change in the bladder } \\
\text { content of AEA and 2-AG in } \\
\text { both WT and FAAH KO }\end{array}$ & [69] \\
\hline Female Wistar rats & LPS-induced cystitis & $\begin{array}{l}\text { LPS }(5 \mathrm{mg} / \mathrm{kg}) \text {, } \\
\text { intravesical instillation }\end{array}$ & $\begin{array}{c}\text { Decreased level of PEA; } \\
\text { Increased level of AEA; } \\
\text { No change in the level of } \\
\text { OEA }\end{array}$ & [67] \\
\hline
\end{tabular}




\subsection{Endocannabinoid Enzymes in IC/BPS}

The levels of endocannabinoid enzymes have rarely been measured in experimental models of IC/BPS. Only two studies have reported the levels of FAAH and NAAA in experimental cystitis models, and FAAH and NAAA remained unaltered in both cases. (Table 3).

Table 3. Endocannabinoid Enzymes in the Bladder Tissue of Experimental IC/BPS Models.

\begin{tabular}{ccccc}
\hline Animals & Condition & $\begin{array}{c}\text { Method of } \\
\text { Induction of IC }\end{array}$ & $\begin{array}{c}\text { Endocannabinoid } \\
\text { Enzymes }\end{array}$ & Reference \\
\hline $\begin{array}{c}\text { Female Wistar } \\
\text { rats }\end{array}$ & $\begin{array}{c}\text { CYP-induced } \\
\text { Cystitis }\end{array}$ & $\begin{array}{c}\text { CYP }(20 \mathrm{mg} / \mathrm{kg}), \text { i.p. } \\
\text { injection }\end{array}$ & $\begin{array}{c}\text { No significant } \\
\text { change in NAAA } \\
\text { mRNA expression }\end{array}$ & [63] \\
\hline $\begin{array}{c}\text { Female Wistar } \\
\text { rats }\end{array}$ & $\begin{array}{c}\text { Acrolein- } \\
\text { induced bladder } \\
\text { inflamma- } \\
\text { tion/hyperalgesia }\end{array}$ & $\begin{array}{c}\text { Acrolein }(1 \mathrm{mM}, \\
\text { 400-ul total volume) } \\
\text { intravesical } \\
\text { instillation }\end{array}$ & $\begin{array}{c}\text { No change in FAAH } \\
\text { protein expression }\end{array}$ & [68] \\
\hline
\end{tabular}

\section{Discussion}

In this review, we have summarized information on the changes in the levels of different components of the ECS in experimental models of IC/BPS as an attempt of identifying potential biomarkers for IC/BPS. Based on currently available data from various experimental studies, we identified CB2R expression, and tissue levels of PEA and AEA look promising as potential biomarkers for IC/BPS as these components were upregulated in the bladder of most of the pre-clinical models of IC/BPS.

Although the ECS has been identified as a potential therapeutic target for the treatment of IC/BPS [50,57,63-65,71], there are not enough studies in which the contents of different components of the ECS have been measured in experimental models of IC/BPS. Moreover, there are discrepancies in the results of the studies reporting ECS components in animal models of IC/BPS. One of the reasons for the discrepancies could be the variations in the animal models being used. The endpoint of the studies and analytical parameters are also variable, which makes it challenging to compare the findings of different studies. In the case of $\mathrm{CB}$ receptors, most of the studies measured the contents of $\mathrm{CB}$ receptors at mRNA levels and on the whole bladder of the animals. It would be very useful if more information were available on the expression of $\mathrm{CB}$ receptors at the protein level in different layers of the bladders in animal models.

Interstitial cystitis is a chronic condition, but the majority of the available data on the contents of individual components of the ECS are from acute IC/BPS models. We came across only one study where a chronic acrolein-induced cystitis model was used [49]. Information on the changes in the levels of components of the ECS using chronic animal models for IC/BPS would be more reliable to derive a conclusion with respect to their values as potential biomarkers for IC/BPS. Moreover, available animal models for studying IC/BPS are chemically induced models, which do not accurately recapitulate the disease from which patients experience. Data obtained from real patients would provide stronger evidence on the changes in the contents of the ECS in the bladder affected by IC/BPS. The study by Mukherji et al., examined the bladder tissue specimens obtained from patients with painful bladder syndrome (PBS) and idiopathic detrusor overactivity (IDO) and showed a significant increase in CB1R-immunoreactive nerve fibers in the suburothelium of PBS and IDO bladders and the detrusor layer of IDO [72].

The studies that we have come across have not reported the content of the components of the ECS in the plasma or urine of the animal models of IC/BPS. When it comes to the diagnosis of a disease, blood or urine samples are easily accessible compared to obtaining tissue samples from an organ like the bladder. The endocannabinoids are synthesized in the body on-demand, and the half-life of the endocannabinoids are very short (minutes). The altered levels of endocannabinoids or the endogenous ligands in the bladder tissue 
may not be reflected in blood due to their short half-lives and presence of various metabolic enzymes in the blood. Urine can be analyzed to check whether the changes in the tissue levels of the endocannabinoids or PEA or AEA are reflected in the urine. In a study involving bladder cancer patients, urine samples were analyzed for the contents of ethanol amides. That study reported upregulation of AEA, PEA, N-stearoylethanolamide, and $\mathrm{N}$-linolenoylethanolamide in the urine samples of patients with bladder cancer [73]. NAAA level was also reported to be upregulated in the urine of bladder cancer patients in that study [73]. Similar studies should be conducted involving IC/BPS patients to obtain information about the contents of endocannabinoids or ECS-metabolizing enzymes in the urine of IC/BPS patients, which would be valuable in identifying a biomarker for IC/BPS in a non-invasive manner.

\section{Conclusions}

As studies have shown strong links between the ECS and bladder function both in normal and pathological conditions, there is a strong possibility that components of the ECS, especially the endocannabinoid ligands, fatty acid amides, and CB2R, can serve as biomarkers for IC/BPS. More studies using carefully designed disease models and clearly defined analytical parameters are required to obtain more convincing data on the components of the ECS in IC/BPS. Additionally, promising findings from pre-clinical studies should be followed by well-structured clinical studies to determine whether any component of the ECS can work as a diagnostic biomarker for IC/BPS.

Author Contributions: Conceptualization, C.L. and S.S.; literature search, S.S.; writing, review, and editing, S.S. and G.B. All authors have read and agreed to the published version of the manuscript.

Funding: This research received no external funding.

Institutional Review Board Statement: Not applicable. This study did not involve humans or animals.

Informed Consent Statement: Not applicable. This study did not involve humans or animals.

Data Availability Statement: Data sharing is not applicable to this article. No new data were created or analyzed in this study.

Conflicts of Interest: The authors declare no conflict of interest.

$\begin{array}{ll}\text { Abbreviations } & \\ \text { 2-AG } & \text { 2-Arachidonoylglycerol } \\ \text { AEA } & \text { Anandamide } \\ \text { APF } & \text { Antiproliferative factor } \\ \text { BPS } & \text { Bladder pain syndrome } \\ \text { CB1R } & \text { Cannabinoid receptor type 1 } \\ \text { CB2R } & \text { Cannabinoid receptor type 2 } \\ \text { CYP } & \text { Cyclophosphamide } \\ \text { EC } & \text { Endocannabinoid } \\ \text { ECS } & \text { Endogenous cannabinoid system } \\ \text { EGF } & \text { Epidermal growth factor } \\ \text { FAAH } & \text { Fatty acid amide hydrolase } \\ \text { HB-EGF } & \text { Heparin-binding epidermal growth factor } \\ \text { IC } & \text { Interstitial cystitis } \\ \text { IDO } & \text { Idiopathic detrusor overactivity } \\ \text { IL-6 } & \text { Interleukin-6 } \\ \text { IL-8 } & \text { Interleukin-8 } \\ \text { IL-1 } \beta & \text { Interleukin-1 } \beta \\ \text { TNF- } \alpha & \text { Tumor necrosis factor- } \alpha \\ \text { i.p. } & \text { Intraperitoneal } \\ \text { LPS } & \text { Lipopolysaccharide }\end{array}$




$\begin{array}{ll}\text { MAGL } & \text { Monoacylglycerol lipase } \\ \text { mRNA } & \text { messenger ribonucleic acid } \\ \text { NAAA } & \text { N-acylethanolamine acid amide hydrolase } \\ \text { NGF } & \text { Nerve growth factor } \\ \text { OEA } & \text { Oleoylethanolamide } \\ \text { PEA } & \text { Palmitoylethanolamide } \\ \text { PBS } & \text { Painful bladder syndrome } \\ \text { qPCR } & \text { Quantitative polymerase chain reaction }\end{array}$

\section{References}

1. Ueda, T.; Hanno, P.M.; Saito, R.; Meijlink, J.M.; Yoshimura, N. Current Understanding and Future Perspectives of Interstitial Cystitis/Bladder Pain Syndrome. Int. Neurourol. J. 2021, 25, 99-110. [CrossRef]

2. Han, E.; Nguyen, L.; Sirls, L.; Peters, K. Current best practice management of interstitial cystitis/bladder pain syndrome. Ther. Adv. Urol. 2018, 10, 197-211. [CrossRef]

3. Homma, Y.; Akiyama, Y.; Tomoe, H.; Furuta, A.; Ueda, T.; Maeda, D.; Lin, A.T.; Kuo, H.C.; Lee, M.H.; Oh, S.J.; et al. Clinical guidelines for interstitial cystitis/bladder pain syndrome. Int. J. Urol. 2020, 27, 578-589. [CrossRef] [PubMed]

4. Hanno, P.; Dmochowski, R. Status of international consensus on interstitial cystitis/bladder pain syndrome/painful bladder syndrome: 2008 snapshot. Neurourol. Urodyn. 2009, 28, 274-286. [CrossRef]

5. Bogart, L.M.; Berry, S.H.; Clemens, J.Q. Symptoms of interstitial cystitis, painful bladder syndrome and similar diseases in women: A systematic review. J. Urol. 2007, 177, 450-456. [CrossRef] [PubMed]

6. Berry, S.H.; Bogart, L.M.; Pham, C.; Liu, K.; Nyberg, L.; Stoto, M.; Suttorp, M.; Clemens, J.Q. Development, validation and testing of an epidemiological case definition of interstitial cystitis/painful bladder syndrome. J. Urol. 2010, 183, 1848-1852. [CrossRef] [PubMed]

7. Kuo, H.C. Potential urine and serum biomarkers for patients with bladder pain syndrome/interstitial cystitis. Int. J. Urol. 2014, 21 (Suppl. S1), 34-41. [CrossRef] [PubMed]

8. Bouchelouche, K.; Nordling, J. Recent developments in the management of interstitial cystitis. Curr. Opin. Urol. 2003, 13, 309-313 [CrossRef] [PubMed]

9. Clemens, J.Q.; Meenan, R.T.; Rosetti, M.C.; Gao, S.Y.; Calhoun, E.A. Prevalence and incidence of interstitial cystitis in a managed care population. J. Urol. 2005, 173, 98-102. [CrossRef]

10. Konkle, K.S.; Berry, S.H.; Elliott, M.N.; Hilton, L.; Suttorp, M.J.; Clauw, D.J.; Clemens, J.Q. Comparison of an interstitial cystitis/bladder pain syndrome clinical cohort with symptomatic community women from the RAND Interstitial Cystitis Epidemiology study. J. Urol. 2012, 187, 508-512. [CrossRef]

11. Berry, S.H.; Elliott, M.N.; Suttorp, M.; Bogart, L.M.; Stoto, M.A.; Eggers, P.; Nyberg, L.; Clemens, J.Q. Prevalence of symptoms of bladder pain syndrome/interstitial cystitis among adult females in the United States. J. Urol. 2011, 186, 540-544. [CrossRef]

12. Johnson, J.E.; Johnson, K.E. Ambiguous chronic illness in women: Community health nursing concern. J. Community Health Nurs. 2006, 23, 159-167. [CrossRef]

13. Hanno, P.M.; Burks, D.A.; Clemens, J.Q.; Dmochowski, R.R.; Erickson, D.; Fitzgerald, M.P.; Forrest, J.B.; Gordon, B.; Gray, M.; Mayer, R.D.; et al. AUA guideline for the diagnosis and treatment of interstitial cystitis/bladder pain syndrome. J. Urol. 2011, 185, 2162-2170. [CrossRef]

14. Hanno, P.M.; Erickson, D.; Moldwin, R.; Faraday, M.M. Diagnosis and treatment of interstitial cystitis/bladder pain syndrome: AUA guideline amendment. J. Urol. 2015, 193, 1545-1553. [CrossRef]

15. Lai, H.H.; Krieger, J.N.; Pontari, M.A.; Buchwald, D.; Hou, X.; Landis, J.R. Painful Bladder Filling and Painful Urgency are Distinct Characteristics in Men and Women with Urological Chronic Pelvic Pain Syndromes: A MAPP Research Network Study. J. Urol. 2015, 194, 1634-1641. [CrossRef]

16. Argade, S.; Chermansky, C.; Tyagi, P. Biomarkers for interstitial cystitis/painful bladder syndrome. Womens Health 2016, 12, 87-90. [CrossRef] [PubMed]

17. Byrnes, S.A.; Weigl, B.H. Selecting analytical biomarkers for diagnostic applications: A first principles approach. Expert Rev. Mol. Diagn. 2018, 18, 19-26. [CrossRef] [PubMed]

18. Sant, G.R. Etiology, pathogenesis, and diagnosis of interstitial cystitis. Rev. Urol. 2002, 4 (Suppl. S1), S9-S15. [PubMed]

19. Teichman, J.M.; Moldwin, R. The role of the bladder surface in interstitial cystitis/painful bladder syndrome. Can. J. Urol. 2007, 14, 3599-3607.

20. Ke, Q.-S.; Kuo, H.-C. Pathophysiology of interstitial cystitis/bladder pain syndrome. Tzu Chi Med. J. 2015, 27, 139-144. [CrossRef]

21. Birder, L.A. Pathophysiology of interstitial cystitis. Int. J. Urol. 2019, 26 (Suppl. S1), 12-15. [CrossRef]

22. Neuhaus, J.; Heinrich, M.; Schlichting, N.; Oberbach, A.; Fitzl, G.; Schwalenberg, T.; Horn, L.C.; Stolzenburg, J.U. Structure and function of suburothelial myofibroblasts in the human urinary bladder under normal and pathological conditions. Urol. A 2007, 46, 1197-1202. [CrossRef]

23. Liu, H.-T.; Kuo, H.-C. Biomarkers for patients with interstitial cystitis/bladder pain syndrome. Urol. Sci. 2015, 26, 225-229. [CrossRef] 
24. Hurst, R.E.; Moldwin, R.M.; Mulholland, S.G. Bladder defense molecules, urothelial differentiation, urinary biomarkers, and interstitial cystitis. Urology 2007, 69, 17-23. [CrossRef] [PubMed]

25. Grundy, L.; Caldwell, A.; Brierley, S.M. Mechanisms Underlying Overactive Bladder and Interstitial Cystitis/Painful Bladder Syndrome. Front. Neurosci. 2018, 12, 931. [CrossRef] [PubMed]

26. Shie, J.H.; Liu, H.T.; Kuo, H.C. Increased cell apoptosis of urothelium mediated by inflammation in interstitial cystitis/painful bladder syndrome. Urology 2012, 79, 484.e7-484.e13. [CrossRef] [PubMed]

27. Keay, S.; Zhang, C.O.; Shoenfelt, J.L.; Chai, T.C. Decreased in vitro proliferation of bladder epithelial cells from patients with interstitial cystitis. Urology 2003, 61, 1278-1284. [CrossRef]

28. Moskowitz, M.O.; Byrne, D.S.; Callahan, H.J.; Parsons, C.L.; Valderrama, E.; Moldwin, R.M. Decreased expression of a glycoprotein component of bladder surface mucin (GP1) in interstitial cystitis. J. Urol. 1994, 151, 343-345. [CrossRef]

29. Keay, S.K.; Szekely, Z.; Conrads, T.P.; Veenstra, T.D.; Barchi, J.J., Jr.; Zhang, C.O.; Koch, K.R.; Michejda, C.J. An antiproliferative factor from interstitial cystitis patients is a frizzled 8 protein-related sialoglycopeptide. Proc. Natl. Acad. Sci. USA 2004, 101, 11803-11808. [CrossRef] [PubMed]

30. Keay, S.; Warren, J.W.; Zhang, C.O.; Tu, L.M.; Gordon, D.A.; Whitmore, K.E. Antiproliferative activity is present in bladder but not renal pelvic urine from interstitial cystitis patients. J. Urol. 1999, 162, 1487-1489. [CrossRef]

31. Keay, S.; Seillier-Moiseiwitsch, F.; Zhang, C.O.; Chai, T.C.; Zhang, J. Changes in human bladder epithelial cell gene expression associated with interstitial cystitis or antiproliferative factor treatment. Physiol. Genom. 2003, 14, 107-115. [CrossRef]

32. Kim, J.; Keay, S.K.; Freeman, M.R. Heparin-binding epidermal growth factor-like growth factor functionally antagonizes interstitial cystitis antiproliferative factor via mitogen-activated protein kinase pathway activation. BJU Int. 2009, 103, 541-546. [CrossRef]

33. Chai, T.C.; Zhang, C.O.; Shoenfelt, J.L.; Johnson, H.W., Jr.; Warren, J.W.; Keay, S. Bladder stretch alters urinary heparin-binding epidermal growth factor and antiproliferative factor in patients with interstitial cystitis. J. Urol. 2000, 163, 1440-1444. [CrossRef]

34. Keay, S.; Zhang, C.O.; Chai, T.; Warren, J.; Koch, K.; Grkovic, D.; Colville, H.; Alexander, R. Antiproliferative factor, heparinbinding epidermal growth factor-like growth factor, and epidermal growth factor in men with interstitial cystitis versus chronic pelvic pain syndrome. Urology 2004, 63, 22-26. [CrossRef] [PubMed]

35. Keay, S.K.; Zhang, C.O.; Shoenfelt, J.; Erickson, D.R.; Whitmore, K.; Warren, J.W.; Marvel, R.; Chai, T. Sensitivity and specificity of antiproliferative factor, heparin-binding epidermal growth factor-like growth factor, and epidermal growth factor as urine markers for interstitial cystitis. Urology 2001, 57, 9-14. [CrossRef]

36. Lowe, E.M.; Anand, P.; Terenghi, G.; Williams-Chestnut, R.E.; Sinicropi, D.V.; Osborne, J.L. Increased nerve growth factor levels in the urinary bladder of women with idiopathic sensory urgency and interstitial cystitis. Br. J. Urol. 1997, 79, 572-577. [CrossRef] [PubMed]

37. Kuo, H.C.; Liu, H.T.; Tyagi, P.; Chancellor, M.B. Urinary Nerve Growth Factor Levels in Urinary Tract Diseases with or without Frequency Urgency Symptoms. Low Urin. Tract Symptoms 2010, 2, 88-94. [CrossRef]

38. Liu, H.T.; Tyagi, P.; Chancellor, M.B.; Kuo, H.C. Urinary nerve growth factor level is increased in patients with interstitial cystitis/bladder pain syndrome and decreased in responders to treatment. BJU Int. 2009, 104, 1476-1481. [CrossRef]

39. Colaco, M.; Koslov, D.S.; Keys, T.; Evans, R.J.; Badlani, G.H.; Andersson, K.-E.; Walker, S.J. Correlation of Gene Expression with Bladder Capacity in Interstitial Cystitis/Bladder Pain Syndrome. J. Urol. 2014, 192, 1123-1129. [CrossRef]

40. Tseng, L.-H.; Chen, I.; Chen, M.-Y.; Lee, C.-L.; Lin, Y.-H.; Lloyd, L.K. Genome-based expression profiles as a single standardized microarray platform for the diagnosis of bladder pain syndrome/interstitial cystitis: An array of 139 genes model. Int. Urogynecol. J. 2009, 20, 515-522. [CrossRef]

41. Pacher, P.; Bátkai, S.; Kunos, G. The endocannabinoid system as an emerging target of pharmacotherapy. Pharmacol. Rev. 2006, 58, 389-462. [CrossRef]

42. Pertwee, R.G. The pharmacology of cannabinoid receptors and their ligands: An overview. Int. J. Obes. 2006, 30 (Suppl. S1), S13-S18. [CrossRef] [PubMed]

43. Hillard, C.J. The Endocannabinoid Signaling System in the CNS: A Primer. Int. Rev. Neurobiol. 2015, 125, 1-47. [CrossRef]

44. Tsuboi, K.; Uyama, T.; Okamoto, Y.; Ueda, N. Endocannabinoids and related N-acylethanolamines: Biological activities and metabolism. Inflamm. Regen. 2018, 38, 28. [CrossRef]

45. Lu, H.C.; Mackie, K. An Introduction to the Endogenous Cannabinoid System. Biol. Psychiatry 2016, 79, 516-525. [CrossRef]

46. Christie, S.; Brookes, S.; Zagorodnyuk, V. Endoca.annabinoids in Bladder Sensory Mechanisms in Health and Diseases. Front. Pharmacol. 2021, 12, 1691. [CrossRef] [PubMed]

47. Hedlund, P. Cannabinoids and the endocannabinoid system in lower urinary tract function and dysfunction. Neurourol. Urodyn. 2014, 33, 46-53. [CrossRef] [PubMed]

48. Strittmatter, F.; Gandaglia, G.; Benigni, F.; Bettiga, A.; Rigatti, P.; Montorsi, F.; Gratzke, C.; Stief, C.; Colciago, G.; Hedlund, P. Expression of fatty acid amide hydrolase (FAAH) in human, mouse, and rat urinary bladder and effects of FAAH inhibition on bladder function in awake rats. Eur. Urol. 2012, 61, 98-106. [CrossRef]

49. Merriam, F.V.; Wang, Z.Y.; Guerios, S.D.; Bjorling, D.E. Cannabinoid receptor 2 is increased in acutely and chronically inflamed bladder of rats. Neurosci. Lett. 2008, 445, 130-134. [CrossRef] [PubMed]

50. Wang, Z.Y.; Wang, P.; Bjorling, D.E. Activation of cannabinoid receptor 2 inhibits experimental cystitis. Am. J. Physiol. Regul. Integr. Comp. Physiol. 2013, 304, R846-R853. [CrossRef] 
51. Gratzke, C.; Streng, T.; Park, A.; Christ, G.; Stief, C.G.; Hedlund, P.; Andersson, K.E. Distribution and function of cannabinoid receptors 1 and 2 in the rat, monkey and human bladder. J. Urol. 2009, 181, 1939-1948. [CrossRef]

52. Tyagi, V.; Philips, B.J.; Su, R.; Smaldone, M.C.; Erickson, V.L.; Chancellor, M.B.; Yoshimura, N.; Tyagi, P. Differential expression of functional cannabinoid receptors in human bladder detrusor and urothelium. J. Urol. 2009, 181, 1932-1938. [CrossRef] [PubMed]

53. Tyagi, P.; Tyagi, V.; Yoshimura, N.; Chancellor, M. Functional role of cannabinoid receptors in urinary bladder. Indian J. Urol. 2010 26, 26-35. [CrossRef]

54. Gratzke, C.; Streng, T.; Stief, C.G.; Downs, T.R.; Alroy, I.; Rosenbaum, J.S.; Andersson, K.E.; Hedlund, P. Effects of cannabinor, a novel selective cannabinoid 2 receptor agonist, on bladder function in normal rats. Eur. Urol. 2010, 57, 1093-1100. [CrossRef] [PubMed]

55. Walczak, J.S.; Cervero, F. Local activation of cannabinoid $\mathrm{CB}_{1}$ receptors in the urinary bladder reduces the inflammation-induced sensitization of bladder afferents. Mol. Pain 2011, 7, 31. [CrossRef] [PubMed]

56. Weinhold, P.; Gratzke, C.; Streng, T.; Stief, C.; Andersson, K.E.; Hedlund, P. TRPA1 receptor induced relaxation of the human urethra involves TRPV1 and cannabinoid receptor mediated signals, and cyclooxygenase activation. J. Urol. 2010, 183, 2070-2076. [CrossRef]

57. Bjorling, D.E.; Wang, Z.Y. Potential of Endocannabinoids to Control Bladder Pain. Front. Syst. Neurosci. 2018, 12, 17. [CrossRef]

58. Wang, Z.Y.; Wang, P.; Bjorling, D.E. Treatment with a cannabinoid receptor 2 agonist decreases severity of established cystitis. J. Urol. 2014, 191, 1153-1158. [CrossRef]

59. Farquhar-Smith, W.P.; Jaggar, S.I.; Rice, A.S. Attenuation of nerve growth factor-induced visceral hyperalgesia via cannabinoid $\mathrm{CB}(1)$ and $\mathrm{CB}(2)-$ like receptors. Pain 2002, 97, 11-21. [CrossRef]

60. Martin, R.S.; Luong, L.A.; Welsh, N.J.; Eglen, R.M.; Martin, G.R.; MacLennan, S.J. Effects of cannabinoid receptor agonists on neuronally-evoked contractions of urinary bladder tissues isolated from rat, mouse, pig, dog, monkey and human. $\mathrm{Br}$. $\mathrm{J}$. Pharmacol. 2000, 129, 1707-1715. [CrossRef]

61. Jaggar, S.I.; Hasnie, F.S.; Sellaturay, S.; Rice, A.S. The anti-hyperalgesic actions of the cannabinoid anandamide and the putative CB2 receptor agonist palmitoylethanolamide in visceral and somatic inflammatory pain. Pain 1998, 76, 189-199. [CrossRef]

62. Farquhar-Smith, W.P.; Rice, A.S. Administration of endocannabinoids prevents a referred hyperalgesia associated with inflammation of the urinary bladder. Anesthesiology 2001, 94, 507-513, discussion 506A. [CrossRef] [PubMed]

63. Pessina, F.; Capasso, R.; Borrelli, F.; Aveta, T.; Buono, L.; Valacchi, G.; Fiorenzani, P.; Di Marzo, V.; Orlando, P.; Izzo, A.A. Protective effect of palmitoylethanolamide in a rat model of cystitis. J. Urol. 2015, 193, 1401-1408. [CrossRef] [PubMed]

64. Tambaro, S.; Casu, M.A.; Mastinu, A.; Lazzari, P. Evaluation of selective cannabinoid CB(1) and CB(2) receptor agonists in a mouse model of lipopolysaccharide-induced interstitial cystitis. Eur. J. Pharmacol. 2014, 729, 67-74. [CrossRef]

65. Liu, Q.; Wu, Z.; Liu, Y.; Chen, L.; Zhao, H.; Guo, H.; Zhu, K.; Wang, W.; Chen, S.; Zhou, N.; et al. Cannabinoid receptor 2 activation decreases severity of cyclophosphamide-induced cystitis via regulating autophagy. Neurourol. Urodyn. 2020, 39, 158-169. [CrossRef]

66. Lowe, H.; Toyang, N.; Steele, B.; Bryant, J.; Ngwa, W. The Endocannabinoid System: A Potential Target for the Treatment of Various Diseases. Int. J. Mol. Sci. 2021, 22, 9472. [CrossRef]

67. Charrua, A.; Matos, R.; Oliveira, R.; Marczylo, T.; Nagy, I.; Cruz, F. Fatty acid amide hydrolase inhibition normalises bladder function and reduces pain through normalising the anandamide/palmitoylethanolamine ratio in the inflamed bladder of rats. Naunyn-Schmiedeberg's Arch. Pharmacol. 2020, 393, 263-272. [CrossRef]

68. Merriam, F.V.; Wang, Z.Y.; Hillard, C.J.; Stuhr, K.L.; Bjorling, D.E. Inhibition of fatty acid amide hydrolase suppresses referred hyperalgesia induced by bladder inflammation. BJU Int. 2011, 108, 1145-1149. [CrossRef]

69. Wang, Z.-Y.; Wang, P.; Hillard, C.J.; Bjorling, D.E. Attenuation of Cystitis and Pain Sensation in Mice Lacking Fatty Acid Amide Hydrolase. J. Mol. Neurosci. 2015, 55, 968-976. [CrossRef]

70. Dinis, P.; Charrua, A.; Avelino, A.; Yaqoob, M.; Bevan, S.; Nagy, I.; Cruz, F. Anandamide-evoked activation of vanilloid receptor 1 contributes to the development of bladder hyperreflexia and nociceptive transmission to spinal dorsal horn neurons in cystitis. $J$. Neurosci. 2004, 24, 11253-11263. [CrossRef]

71. Hedlund, P.; Gratzke, C. The endocannabinoid system-A target for the treatment of LUTS? Nat. Rev. Urol. 2016, 13, 463-470. [CrossRef] [PubMed]

72. Mukerji, G.; Yiangou, Y.; Agarwal, S.K.; Anand, P. Increased Cannabinoid Receptor 1-Immunoreactive Nerve Fibers in Overactive and Painful Bladder Disorders and Their Correlation with Symptoms. Urology 2010, 75, 1514.e15-1514.e20. [CrossRef] [PubMed]

73. Vago, R.; Ravelli, A.; Bettiga, A.; Casati, S.; Lavorgna, G.; Benigni, F.; Salonia, A.; Montorsi, F.; Orioli, M.; Ciuffreda, P.; et al. Urine Endocannabinoids as Novel Non-Invasive Biomarkers for Bladder Cancer at Early Stage. Cancers 2020, 12, 870. [CrossRef] [PubMed] 